\title{
Morphology and sedimentation of sand bodies in the tidal shelf sea of eastern Taiwan Strait
}

\author{
Horn-Ru Liao, Ho-Shing Yu*, Chih-Chieh Su \\ Institute of Oceanography, National Taiwan University, Taipei, Taiwan
}

Received 11 May 2006; received in revised form 15 October 2007; accepted 18 October 2007

\begin{abstract}
Changyun Ridge, located in the central-eastern part of the Taiwan Strait, consists of sand bodies: the eastern Changyun Sand Ridge (65 km long and $13 \mathrm{~km}$ wide), a sand shoal (53 km long and $22 \mathrm{~km}$ wide) and a sand sheet (60 km long, $40 \mathrm{~km}$ wide and $22 \mathrm{~m}$ in height). The eastern Changyun Sand Ridge and the sand sheet are oriented parallel to the coastline, but the sand shoal is perpendicular to the coast. The eastern Changyun Sand Ridge is oriented oblique to the narrow reciprocal tidal ellipses. The sand shoal and sand sheet are normal and oblique to the broad rotary tidal ellipses, respectively.

Surface sediments of the Changyun Ridge are composed of very fine-to-coarse sands in a progressive seaward decrease in grain size. The configuration and spatial distribution of these three sand bodies with corresponding decrease in tidal speed and in grain size together suggest that the sand bodies developed sequentially from the near-shore to the offshore area, presumably in response to westward shifting of the north-flowing tidal currents. Sand waves occur widespreadly on the sand shoal and seldom appear on the eastern Changyun Sand Ridge. Occurrences of sand waves suggest that the sand shoal is considered to be active and the sand ridge to be moribund.

Chirp sonar profiles reveal the internal structures of the sand shoal, showing a relatively flat basal reflector underlying the sand body. The thickness of the sand accumulation is about $22-25 \mathrm{~m}$ and it is firstly determined by the depth difference between the modern sea bed and the basal reflector to better describe morphology and document dimensions of these sand bodies. The presence of several short inclined reflectors dipping northeast and down-lapping the basal flat reflector indicate that sands are most likely transported from south to north for the sand shoal. The sand bodies of the Changyun Ridge rest upon a relative flat basal reflector, suggesting a mainly hydrodynamically controlled origin. The variations of the hydrodynamic conditions (mainly tidal currents) on the central-eastern Taiwan Strait shelf seem to be the primary control on sedimentary facies shift, morphological changes and sand ridge growth for the Changyun Ridge. The Changyun Ridge is ongoing to receive sands from the south in a transitional development stage. As long as the sand supply continues, and over a longer time period, the sand bodies eventually will develop into three individual linear sand ridges separated by swales oriented parallel to the peak currents.
\end{abstract}

(C) 2007 Elsevier B.V. All rights reserved.

\footnotetext{
* Corresponding author.

E-mail address: yuhs@ntu.edu.tw (H.-S. Yu).
} 


\section{Introduction}

More than 40 years ago, Off (1963) pointed out that the Taiwan Strait, a waterway between Mainland China and Taiwan, is a relatively shallow shelf sea (average $60 \mathrm{~m}$ in water depth) dominated by tidal currents (Fig. 1). The Taiwan Strait shelf is one of several modern shelves characterized by semidiurnal tides with large tidal ranges (3-4 m) and strong surface currents ( 0.6 to $1.0 \mathrm{~m} / \mathrm{s})$. By analogy to linear sand ridges present on the shallow tidal seas worldwide, he further postulated that there should be tidal sand ridges present in the Taiwan Strait. Little attention was paid to his comments on tidal sand ridges by the Taiwanese marine scientists.

Based on the occurrence of tidal sand ridges on the shelf of Bohai Sea off north-eastern China, Liu et al. (1998) postulated that the Taiwan Strait is a modern tidal depositional system that consists of two tidal erosional and depositional geomorphic units. The paired Penghu Channel (scour furrow) and Changyun Ridge (sand ridge) occur in the south-eastern part of the Taiwan Strait. The other one consists of the scour furrow of the Wuchu Depression and the Taiwan Banks (sand ridges) in the central and southern Taiwan Strait (Fig. 1).

The hypothesis proposed by Liu et al. (1998) was from the first marine scientists to pay attention to the Penghu Channel and the Changyun Ridge in terms of tidal erosion and deposition. Huang and Yu (2003) conducted a high-frequency $(3.5 \mathrm{kHz})$ sub-bottom survey with $33 \mathrm{E}-\mathrm{W}$ trending profiles across the Penghu Channel, revealing irregular channel floors with high relief, ranging from 10 to $30 \mathrm{~m}$ suggesting an erosive scour channel. Wang et al. (2004) were the first team to conduct a field survey with a ship-borne acoustic Doppler current profiler across the Penghu Channel and found that currents in the Penghu Channel are essentially barotropic and characterized by strong semidiurnal tides and mean flow. The mean current is uniform with an average northward velocity of $0.73 \mathrm{~m} / \mathrm{s}$ in the Penghu Channel.

Combined results of both studies of Huang and $\mathrm{Yu}$ (2003) and Wang et al. (2004) infer the Penghu Channel to be a scour channel mainly formed by erosion by north-flowing tidal currents. Later, Liao and Yu (2005) began to investigate the Changyun Ridge immediately north of the Penghu Channel to determine whether or not the Changyun Ridge is a tidal sand ridge coupled with the tidal scour furrows to the south. The topographic high, confined by the 40-m isobath north of the Penghu Channel, was named as the Changyun Sand Ridge by Wang and Chern (1989), physical oceanographers at the Institute of Oceanography,
National Taiwan University (Fig. 2a). They emphasized the topographic effects of the Changyun Sand Ridge on the flow patterns of the currents in the Taiwan Strait, but provided no information on sediment characteristics and morphology. Later, Liao and Yu (2005) studied cored sediment samples and analyzed bathymetric data in more detail and concluded that the Changyun Ridge is a tide-dominated sand body.

This ridge is defined by the $50-\mathrm{m}$ isobath and consists of two smaller ridges. The eastern Changyun ridge is about $65 \mathrm{~km}$ long and $15 \mathrm{~km}$ wide and approximately parallel to the shoreline of western Taiwan. The western Changyun ridge has a length of $53 \mathrm{~km}$ and a maximum width of $26 \mathrm{~km}$, trending northwest-southeast normal to the coast. A swale of about $30 \mathrm{~m}$ in water depth lies between these two sand ridges (Fig. 2b). The eastern ridge has morphological characteristics similar to those of typical linear sand ridges (Dyer and Huntley, 1999). The western one is different from typical sand ridges in terms of morphology and orientation. Large to verylarge sand waves occur on the western Changyun Ridge and sand waves seldom appear on the eastern Changyun Ridge, implying that the former is presently active while the latter becomes inactive or moribund. Judging the configuration and distribution of these two ridges, Liao and $\mathrm{Yu}$ (2005) further suggested that the ridges developed sequentially from the near-shore to the offshore, presumably in response to a westward shifting of the north-flowing tidal currents and resulting in an across-shore transport of sediment.

Apparently, the paired Changyun Ridge and the Penghu Channel reported by Liao and Yu (2005) is different from the general spatial distribution of sand ridges and the associated channel where a series of linear sand ridges alternating with troughs (or swales) are connected to the nearby tidal channel (scour furrow). For example, six linear sand ridges alternating with swales are located immediately north of the Laotieshan Channel (scour furrow) on the eastern Bohai shelf (Liu et al., 1998). Morphological characteristics of the plan form of the western Changyun ridge were not well described by Liao and $\mathrm{Yu}$ (2005) due to insufficient data availability. The height of these sand bodies, in particular, was not determined because high-resolution reflection profiles, such as the chirp sonar reflection data were unavailable. It is necessary to examine dimensions of these sand bodies in greater details to better define their morphology compared to that of typical sand ridges. Relationships between tidal currents, sand ridge morphology and sediment transport routes are investigated here to better explain the occurrence of sand ridges on the eastern Taiwan Strait. The purpose of this 


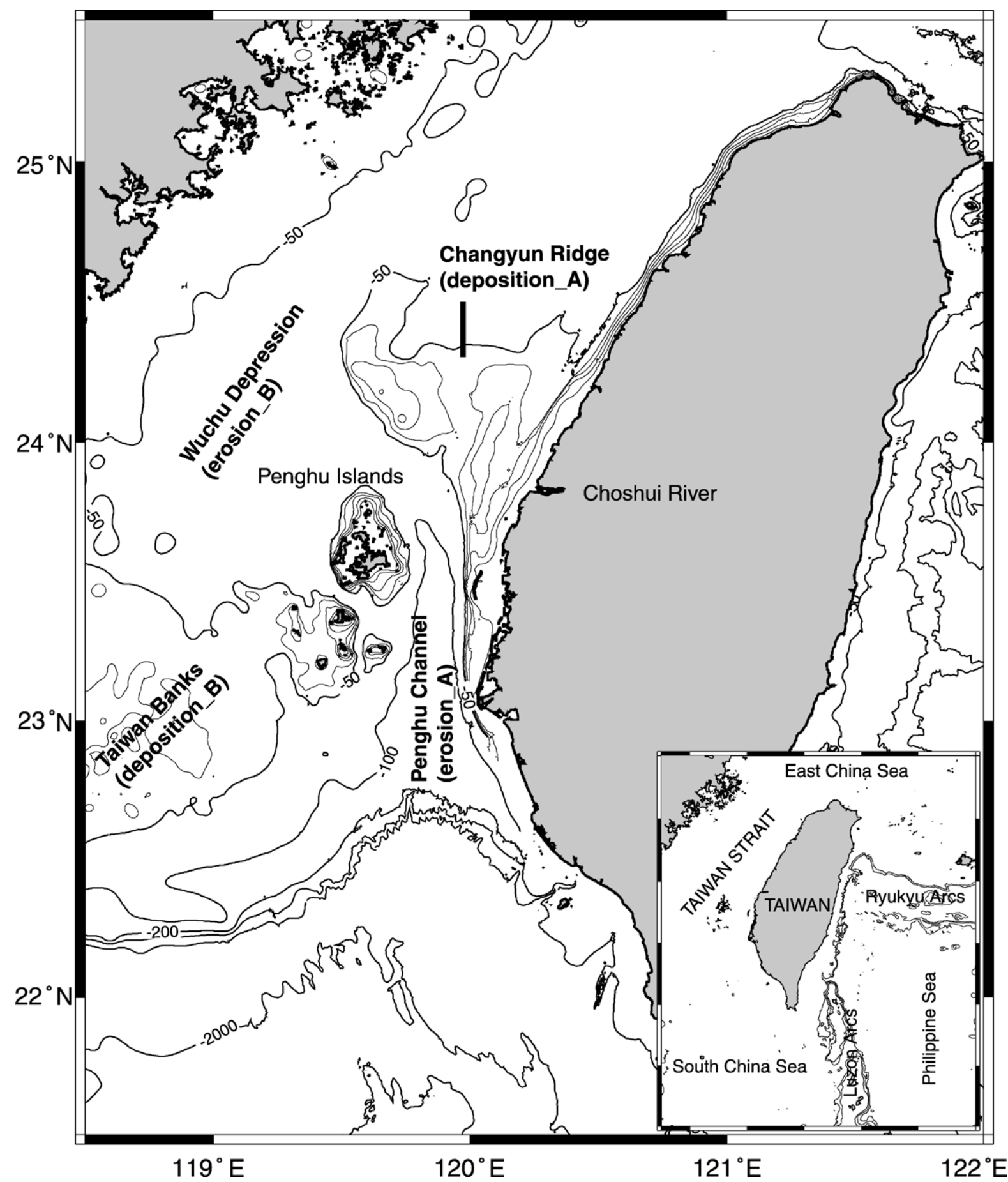

Fig. 1. Bathymetric map showing the shallow shelf off the western Taiwan coast characterized by three prominent topographic features. Located west of the Choshui River in west-central Taiwan, the Changyun Ridge is connected to the funnel-shaped Penghu Channel to the south. The other two less prominent subsea features of the Wuchu Depression and the Taiwan Banks occur in the central and southern Taiwan Strait, respectively. The postulated paired erosive Penghu Channel and the depositional Changyun Ridge is labeled as the A feature. The other erosion-deposition morpho/ sedimentary pair is labeled as the B feature. The right-lower inset shows the geologic setting of the island of Taiwan. 

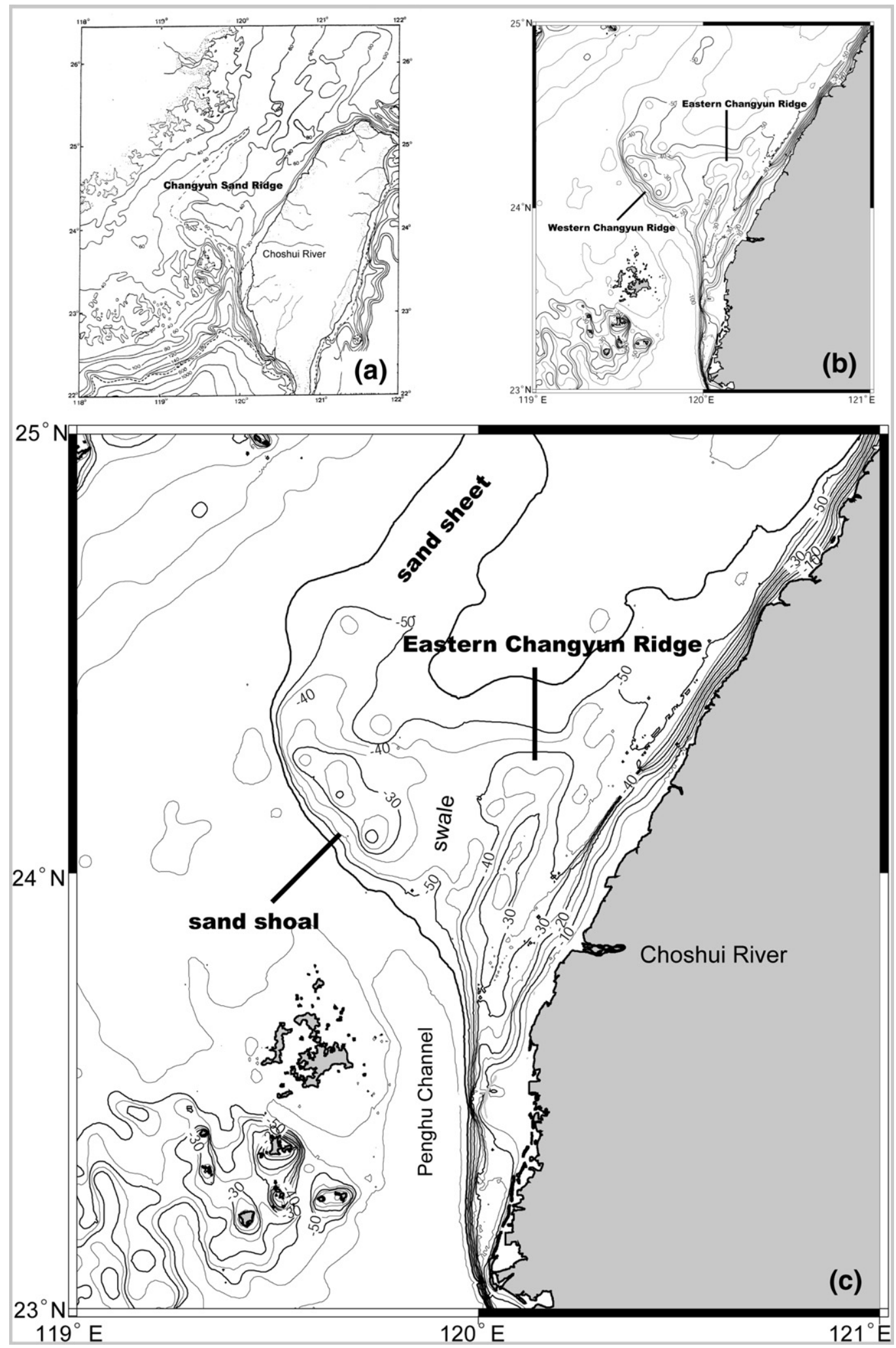
paper is to present newly collected high-resolution chirp data and cored sediments at the west Changyun Ridge. We analysed all available surficial core samples over the sand bodies of the Changyun Ridge to relate its formation to tidal currents, and sediment transport, and to integrate results into the tidal erosion and deposition system of Taiwan Strait.

\section{Regional geological setting and environments}

The island of Taiwan is located at the junction of the Luzon and Ryukyu Arcs in the north-western Pacific (Fig. 1). Oblique collision between the passive margin of the Chinese continent and the northern Luzon Arc resulted in the fold-thrust mountain belt of Taiwan and the western Taiwan foreland basin flanking the rising mountain ranges in the Late Cenozoic (Biq, 1997; Suppe, 1981; Ho, 1988). This island is bordered to the west by the relatively shallow Taiwan Strait and by the deep Philippine Sea to the east. The Taiwan Strait has a length of more than $300 \mathrm{~km}$ and varies in width (140 to $200 \mathrm{~km}$ ) between the eastern coast of Mainland China and the western shoreline of Taiwan (Fig. 1). Taiwan Strait shelf is the distal part of the western Taiwan foreland basin which is a sedimentary wedge of Pliocene-Quaternary sediment up to $5000 \mathrm{~m}$ thick derived from the Taiwan orogen (Covey, 1984; Yu and Chou, 2001). The floors of the Taiwan Strait are covered by a thin veneer of Late Pleistocene to Holocene sediments with varying relict, palimpsest and modern sediment origin (Boggs et al., 1979).

Two distinct morphological features are present in the eastern Taiwan Strait off the central-south Taiwan coast. One is the prominent Changyun Ridge, a bathymetric high confined by a $50-\mathrm{m}$ isobath, extending westward about $90 \mathrm{~km}$ from the shoreline of western Taiwan, forming an E-W trending bathymetric high (Fig. 1). The other is the $\mathrm{N}-\mathrm{S}$ trending Penghu Channel immediately south of this ridge. It occupies the waterway between the Penghu Islands and south-western Taiwan and extends southwards to the northern slope of the South China Sea. Detailed descriptions of the topography of sea floors of the Taiwan Strait shelf can be found in refer Boggs et al. (1979), Mao and Hsieh (1989), Yu and Chou (2001) and Yu (2003).

There are complex patterns of currents in the Taiwan Strait. The currents are dominated by monsoons, tides, and topography. Currents in the Taiwan region vary seasonally as they are controlled by the monsoon winds (Liang et al., 2003). However, currents in the eastern Taiwan Strait are not only affected by seasonal sea surface wind stresses, but also by the topographic relief of the Changyun Ridge and the Penghu Channel (Fan, 1982; Wang and Chern, 1989; Jan et al., 2002). During the summer season, the South China Sea surface waters, driven by the south-westerly summer monsoon and Kuroshio enter into the Taiwan Strait through the Penghu Channel (Fig. 3). The light surface waters flow over the Changyun Ridge and continue their northeast path along the western coast of Taiwan and finally merge into the East China Sea. In contrast, the heavy bottom waters (Kuroshio) coming from the Penghu Channel are blocked in front of the Changyun Ridge and then are deflected north-westward. In the winter season, the northward flowing South China Sea waters through the Penghu Channel are retarded by the north-easterly winter monsoon and turn north-westward along the southern edge of the Changyun Ridge. In the northern Taiwan Strait, the southward cold and fresh China Coastal currents turn cyclonically at the northern edge of the Changyun Ridge, forming a cyclonical cold eddy. A zonal oceanic front develops on the Changyun Ridge. Jan et al. (2002) gave a detailed description of the seasonal circulation of currents in the Taiwan Strait.

The other current is the tidal current. Wang et al. (2003) have compiled available data of tidal currents in the Taiwan Strait and reported that the yearly average tidal current is $0.46 \mathrm{~m} / \mathrm{s}$, with maximum amplitudes at the northeast and southeast entrances. Jan et al. (2004) developed a 3D tidal model for tides in the Taiwan Strait, showing semidiurnal tides being predominant. Tidal currents are strong near the open ends of the Taiwan Strait, especially on the Taiwan side, and diminish towards the middle of the strait. There were only two direct flow measurements in the Penghu Channel. Chuang $(1985,1986)$ used moored current meters to collect flow data and Wang et al. (2004) used a ship-borne ADCP to map the flow field across the Penghu Channel. The former found a northward mean current of $0.27 \mathrm{~m} / \mathrm{s}$ and tidal currents to about $1 \mathrm{~m} / \mathrm{s}$. The latter determined that tidal velocities are $1.20 \mathrm{~m} / \mathrm{s}$ and $0.32 \mathrm{~m} / \mathrm{s}$. The funnel-shaped Penghu Channel serves as a gate for water mass fluxes into the Taiwan Strait from the South China Sea. Jan and Chao (2003) estimated that

Fig. 2. The bathymetric Changyun Sand Ridge was loosely defined by Wang and Chern (1989). The Changyun Sand Ridge is characterized by a triangle shape tapering west bounded by longitude $119^{\circ} 30^{\prime \prime} \mathrm{E}$. (a). The Changyun Ridge is further divided into two bathymetric high features: the eastern Changyun Ridge and the western Changyun Ridge separated by a swale (Liao and Yu, 2005) (b). The Changyun Ridge consists of three sand bodies: the eastern Changyun Sand Ridge, a sand shoal and a sand sheet (this paper) (c). 

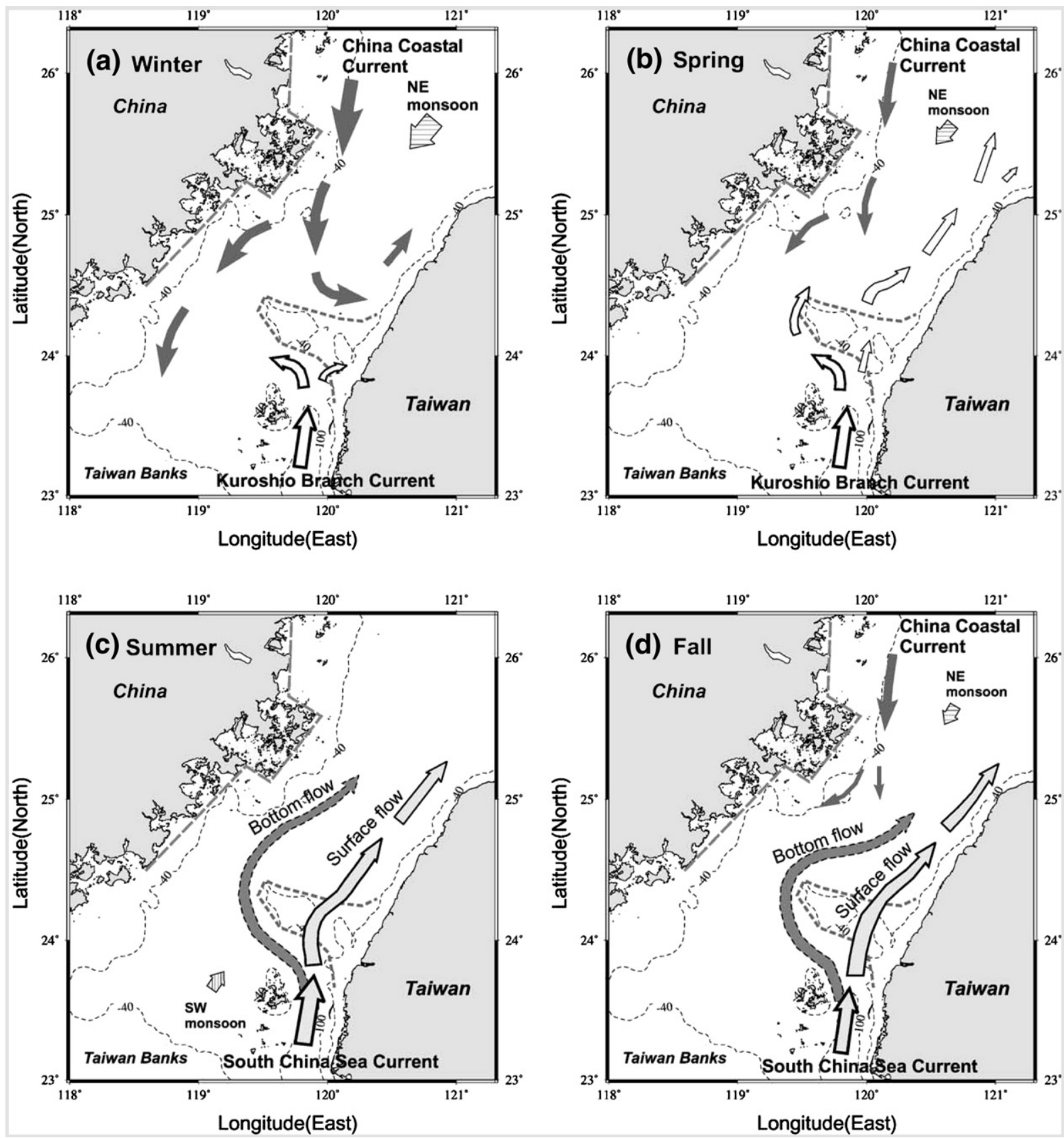

Fig. 3. The seasonal circulation of currents in the Taiwan Strait (Jan et al., 2002). Note that currents coming from the Penghu Channel at the outlet of the channel are deflected to the northwest in front of the Changyun Ridge in winter and spring. In summer and fall seasons, north-flowing currents aided by southwest monsoon flow over the Changyun Ridge and continue their north-flowing trend into the East China Sea.

velocities, after removing semidiurnal tides, are high in the Penghu Channel flowing northward with a speed of up to $1 \mathrm{~m} / \mathrm{s}$ in the upper $50 \mathrm{~m}$ during the summer. The estimated water transport volume out of the Penghu Channel reaches a maximum of $1.5 \mathrm{~Sv}$ by the end of the summer. Lin et al. (2005) reported that a short-term

Fig. 4. Bathymetric and chirp sonar profiles and surface sediments over the western Changyun Ridge were collected on board R/V Ocean Research I during 2005. Seven chirp sonar profiles across the long axis of the sand shoal and two chirp profiles along the long axis were acquired to reveal the internal structures of sand bodies. In total, 23 core samples were collected amongst which 6 samples were taken along the axis of the Wuchu Depression. 


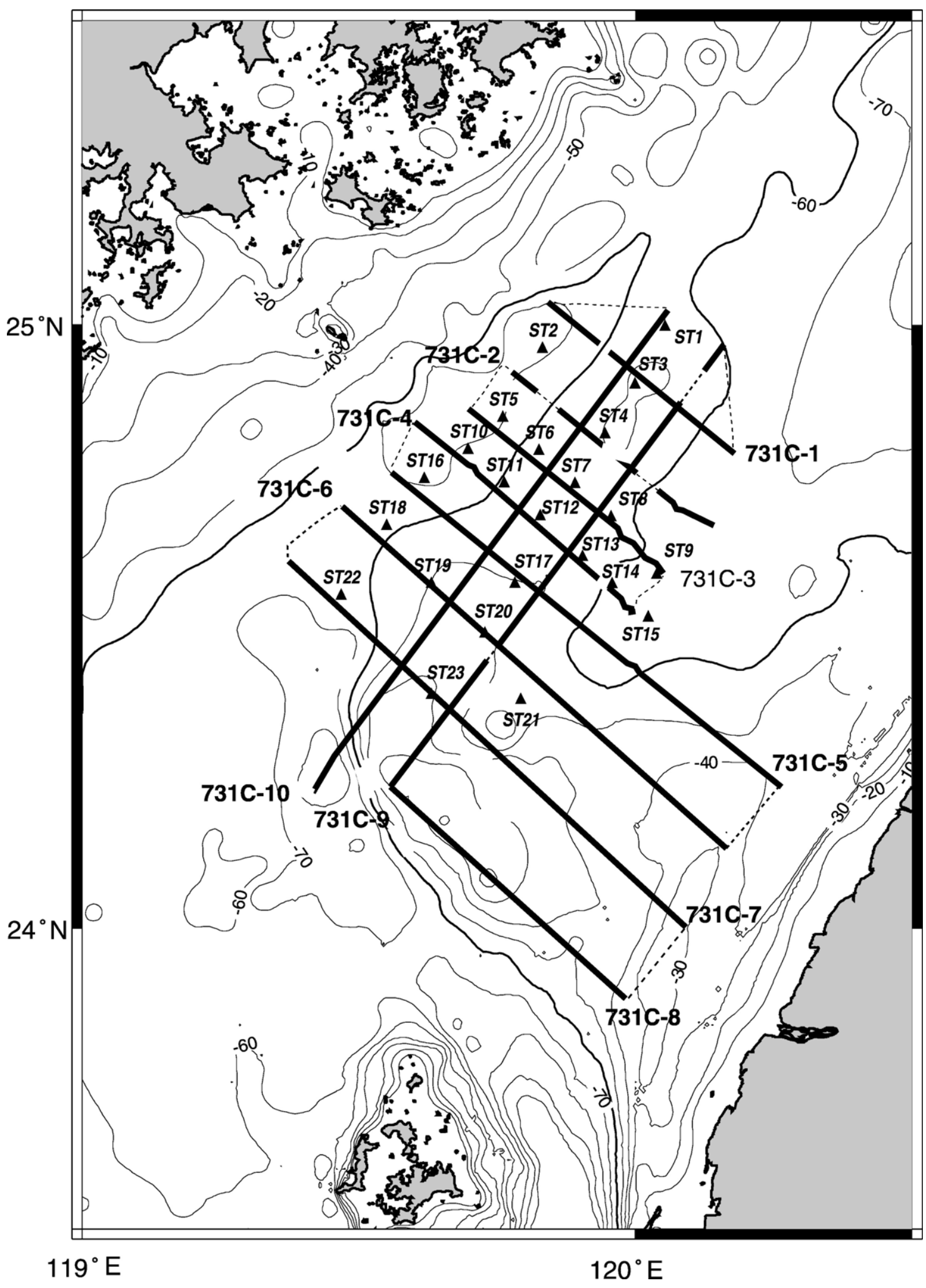


current measurement at the northern tip of the Penghu Channel showed a consistently northward flow originating from the Penghu Channel that could have a significant impact on the north-flowing tidal currents along the Taiwan Strait.

\section{Methods}

Bathymetric profiles, chirp sonar sub-bottom profiles and cored surface sediment samples covering the western Changyun ridge areas were collected by two short cruises on aboard R/V Ocean Researcher I and II during 2004-2005 (Fig. 4). Bathymetric and chirp sonar profiles are oriented NW-SE normal to the long axes of the sand bodies, except two profiles oriented NE-SW parallel to the long axis of the western Changyun ridge. Bathymetric data were integrated into the databank of bathymetry at the National Centre for Ocean Research. Bathymetric data (each datum point every $100 \mathrm{~m}$ ) were then gridded and contoured using the GMT system to make bathymetric charts in the study areas. A BATHY-2000P Chirp Sub-Bottom Profiler (Ocean Data Equipment Corporation) was used to collect high-resolution chirp reflection profiles at an average spacing of $15 \mathrm{~km}$ over a $\sim 7500 \mathrm{~km}^{2}$ area. The resolution of the sub-bottom recording is $8 \mathrm{~cm}$ with 100 to $200 \mathrm{~m}$ sub-bottom penetration. The chirp bandwidth ranges from 3 to $11 \mathrm{kHz}$. A total of 31 surficial box-cored samples were acquired, 8 of which are located along the crest of the sheet. We used the Beckman Coulter LS-13 320 Laser diffraction particle size analyzer to determine the grain-size distribution of these sediment samples.

\section{Results}

\subsection{Morphology}

The bathymetric mapping indicates that the western Changyun ridge is separated by a swale of about 8 to $10 \mathrm{~km}$ wide and $50 \mathrm{~m}$ in water depth from the eastern Changyun Ridge (Fig. 2b). It is distinguished by two different morphological units, with a different orientation. A sharp turn or kink of about $90^{\circ}$ occurs at the western tip of the Changyun Ridge. The southern unit defined by a $40-\mathrm{m}$ isobath, oriented NW-SE normal to the shoreline of western Taiwan, has a length of about $50 \mathrm{~km}$, a width ranging from 13 to $50 \mathrm{~km}$ and a height above the sea floor varying from 20 to $30 \mathrm{~m}$. The crest zone of the southern unit of the western Changyun ridge is outlined by a $30-\mathrm{m}$ isobath and the crest line is offset south-westward, causing an asymmetry in the cross section. The southern steep side is about $0.23^{\circ}$ whereas the northern gentle slope varies from 0.006 to $0.11^{\circ}$.

The northern unit of the western Changyun ridge, loosely defined by the $60-\mathrm{m}$ isobath and oriented NESW parallel to the shoreline of western Taiwan, is located between the Wuchu Depression to the west and the Kuanyin Depression to the east. The long axis of the elongated feature extends for a distance of about $85 \mathrm{~km}$. The width of the cross sections does not vary much, averaging about $40 \mathrm{~km}$. The plan form of this linear feature has a rectangular shape with a length-to-width ratio of 2 to 1 . This elongated feature shows symmetrical cross section with slope angles about 0.04 to $0.09^{\circ}$ for both sides. The crest line is more or less located in the middle of the elongated feature. The top of the linear feature is about $43 \mathrm{~m}$ at the south end and increases in depth to about $50 \mathrm{~m}$ within a distance of $28 \mathrm{~km}$ and gradually increases in depth to about $60 \mathrm{~m}$ at the northern end.

\subsection{Sediment characteristics}

The grain-size distribution of surface sediments on the sand sheet ranges from 2.55 to 5.32 phi, mainly belonging to very fine-grained sands. Eight cores have been collected along the crest of the sand sheet (Fig. 5). The cores mainly consist of very fine sands with one exception being fine sand (ST. 12, Fig. 5). Three cores were collected on the western flank of the sand sheet, consisting of very fine and fine sands. Four cored samples were collected on the eastern flank of the sand sheet and consist mainly of very fine sands. These very fine-grained sands are moderately-well sorted (0.56 phi). Liao and Yu (2005) reported that the surface sediments along the crest of the sand shoal are characterized by medium-grained sands ranging from 1.35 to 2.00 phi (Fig. 5). The surface sediments on the eastern Changyun Sand Ridge are characteristic of medium-to-coarse sands between 0.16 and 1.78 phi (Fig. 5). It is clear that the surface sediments of these

Fig. 5. The crest zones of eastern Changyun Sand Ridge and the sand shoal are dominated by medium-to-coarse-grained sands and fine-to-mediumgrained sands, respectively. Surface sediments over the sand sheet are mainly composed of very fine sands. Grain-size analyses show a progressive across-strait decrease in grain size. The scale of grain size is phi. The gray patterns indicate where the sand waves appear. Sand waves occur widespread on the sand shoal, but sand waves seldom appear on the eastern Changyun Sand Ridge. 


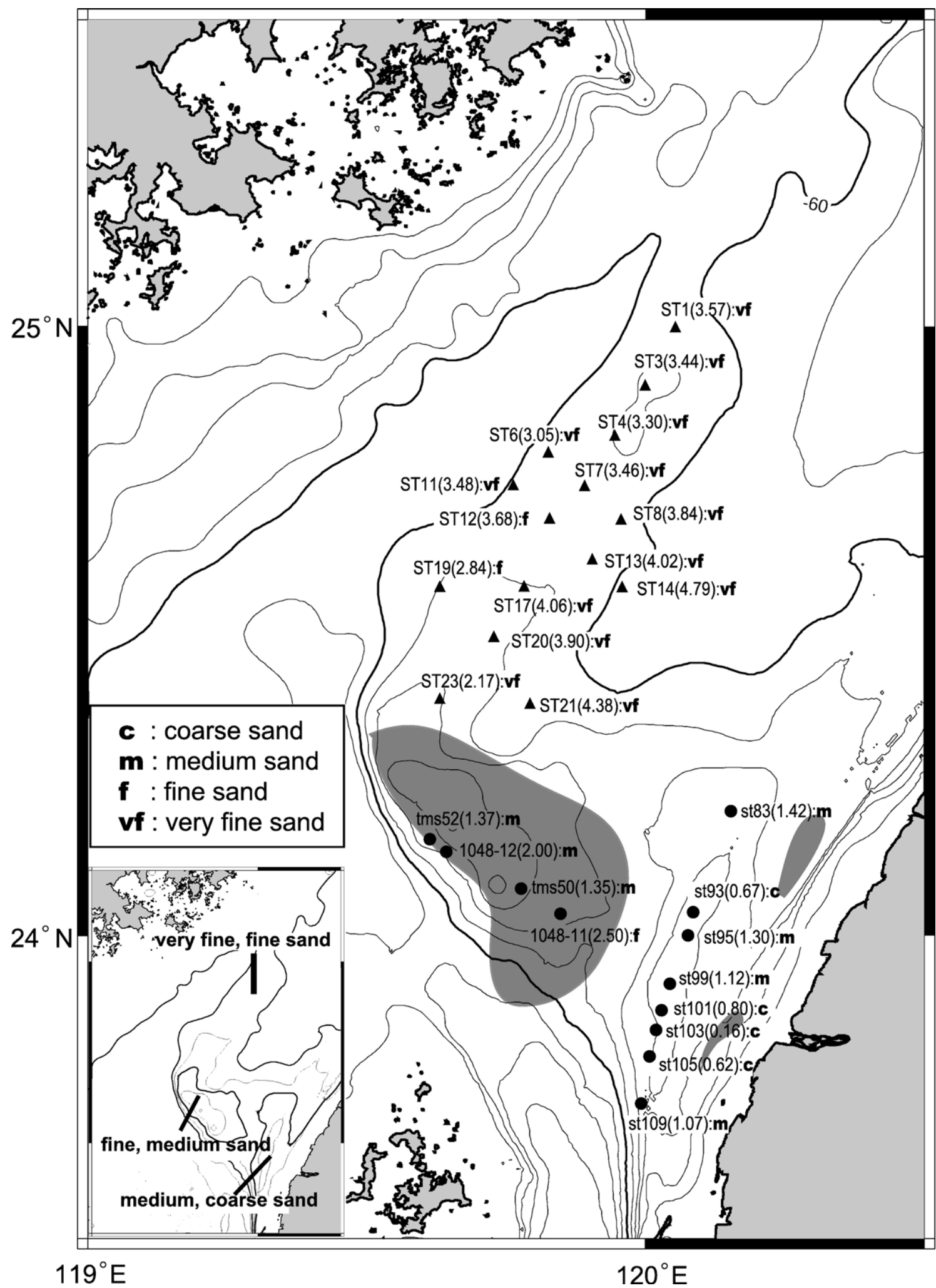


three sand bodies show a progressive decrease in grain size from coarse to very fine sands with a typical transition from a sand ridge to a sand shoal.

Abundant sand waves occur on the sand shoal and the sand sheet, and sand waves seldom appear on the eastern Changyun Sand Ridge. Most large sand waves on the western sand shoal show asymmetrical crosssectional profiles (Fig. 5).

\subsection{Chirp sub-bottom profiles}

Chirp sonar profiles show a common feature that is a basal reflection at about $75 \mathrm{~m}$ in water depth. This basal reflection becomes shallower and more indistinct from west to east. The thickness of sand accumulation above the basal reflection is about $22-25 \mathrm{~m}$. There are some differences in reflection patterns between the latitudinal profiles $(\mathrm{E}-\mathrm{W})$ and the longitudinal profiles $(\mathrm{S}-\mathrm{N})$. For example, chirp sonar profiles 731C-4 through 731C-6, across the long axis of the sand sheet, show that relatively flat basal reflectors are underlying the main bodies of the sand sheet. The basal reflectors become shallow and uneven with a minor relief towards the eastern Changyun Sand Ridge (Fig. 6).

Longitudinal chirp sonar profiles of $735 \mathrm{C}-9$ and $735 \mathrm{C}-10$, along the sand shoal and sand sheet, show different internal structures of the sand bodies with additional short inclined reflectors dipping northeast between the sea bed and the relatively flat basal reflectors (Fig. 7).

\subsection{Summary of observations}

Systematic variations between morphology, sediment characteristics and tidal ellipses on sand bodies of the Changyun Ridge are observed, as presented in Table 1 and used for discussion in the following section.

\section{Discussions}

\subsection{Type of sand bodies}

Sand ridges or sand banks in tidal shelf seas are typically tens of kilometers in length and can be up to $80 \mathrm{~km}$ long and about $13 \mathrm{~km}$ wide and tens of meters high (Dyer and Huntley, 1999; Williams et al., 2000).
For example, sand banks on the Celtic Sea shelf are $70 \mathrm{~km}$ long, $7 \mathrm{~km}$ wide, up to $50 \mathrm{~m}$ high, and about $16 \mathrm{~km}$ apart (Marsset et al., 1999; Reynaud et al., 1999a, 1999b; Berné et al., 1998; 2002). The longest sand ridges in the Celtic Sea are 80-200 km (Berné et al., 1998), whereas in Donghai (the East China Sea) the length is about $120 \mathrm{~km}$ (Liu et al., 1998). Dimensions of the western Changyun ridge, including the southern and northern parts, are not comparable to those of the common sand ridges, suggesting that they are a different type of feature and that they may have formed under different environmental conditions. Specifically, the northern unit of the western Changyun ridge is an elongated sand body without the characteristic shape of tidal sand ridges or banks. A sand sheet is more suitable for its morphological characteristics. The southern sand body may be better called a sand shoal. Based on morphological characteristics and orientations of the long axis of sand bodies, we consider that the Changyun Ridge consists of three sand bodies across-shore from the east to west: the eastern Changyun Sand Ridge, a sand shoal and a sand sheet (Fig. 2c).

\subsection{Sedimentation}

A large amount of sand supply and sufficiently strong currents are required to form sand ridges or banks on the shallow shelf seas (Dyer and Huntley, 1999; Deleu et al., 2004; Williams et al., 2000). The prevailing sediment transport direction and variations of grain size of sand bodies of the Changyun Sand Ridge are inferred by several lines of evidence from morphology, internal structures and tidal current patterns (Figs. 6, 7 and 8). The plan form of sand banks can be used to indicate the approximate direction of net sand transport (Caston, 1981). For example, sand banks in the Southern Bight of the North Sea show rounded heads in the upstream direction and tapered tails or ends in the downstream direction of net regional sand transport. In plan view, the isobaths of $30 \mathrm{~m}$ and $40 \mathrm{~m}$ of the sand shoal show northwest tapering of its tail (Fig. 2c), indicating sands are mainly transported in a northwest direction. The isobath of $50 \mathrm{~m}$ becomes narrower towards the northeast with a tapering end for the sand shoal (Fig. 2c), indicating a northeast direction of net sand transport. However, the morphological difference between the

Fig. 6. Chirp sonar profiles $731 \mathrm{C}-4$ through $731 \mathrm{C}-6$ across the long axis of the sand shoal show that relatively flat basal reflectors are underlying the main bodies of the sand shoal. The basal reflectors become shallow and uneven with a minor relief towards the eastern Changyun Sand Ridges. The height of the sand shoal can be determined by the difference in depth between the top of the sand shoal and the basal reflector. It ranges from 22 to $25 \mathrm{~m}$ in thickness. The depths of the basal reflectors are comparable to those appearing on profiles $731 \mathrm{C}-4$ through $731 \mathrm{C}-6$. Locations of chirp sonar profiles are shown in Fig. 4. 
om $731 \mathrm{C}-4$

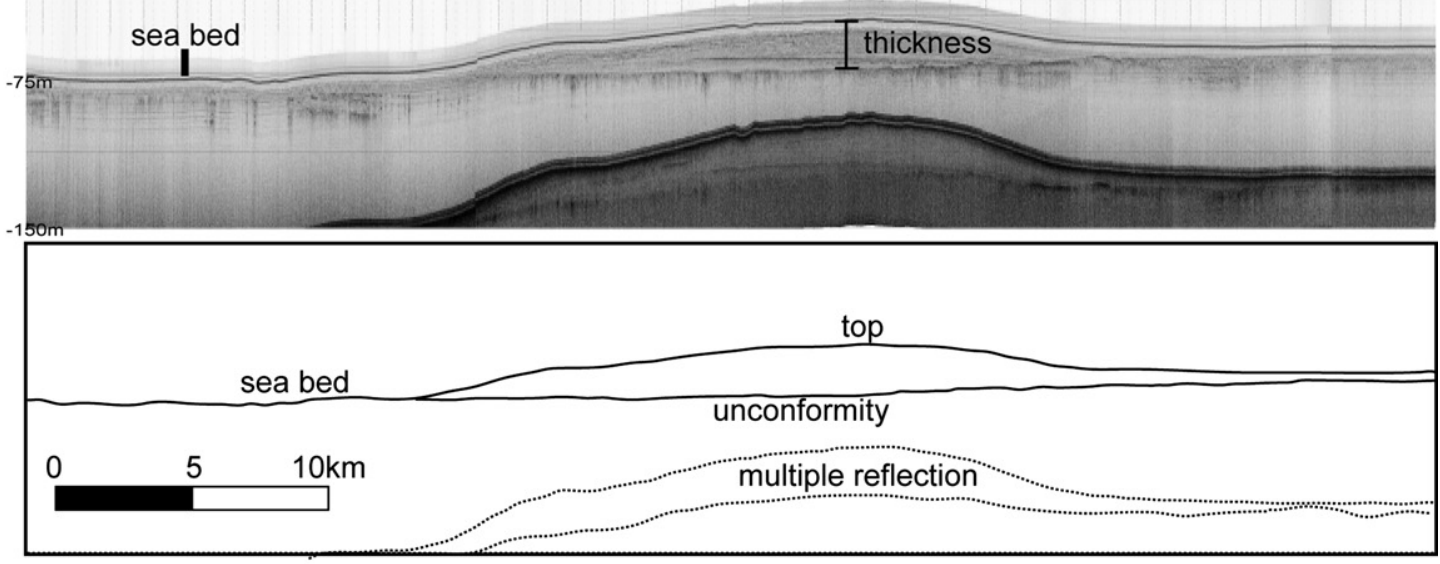

om 731C-5
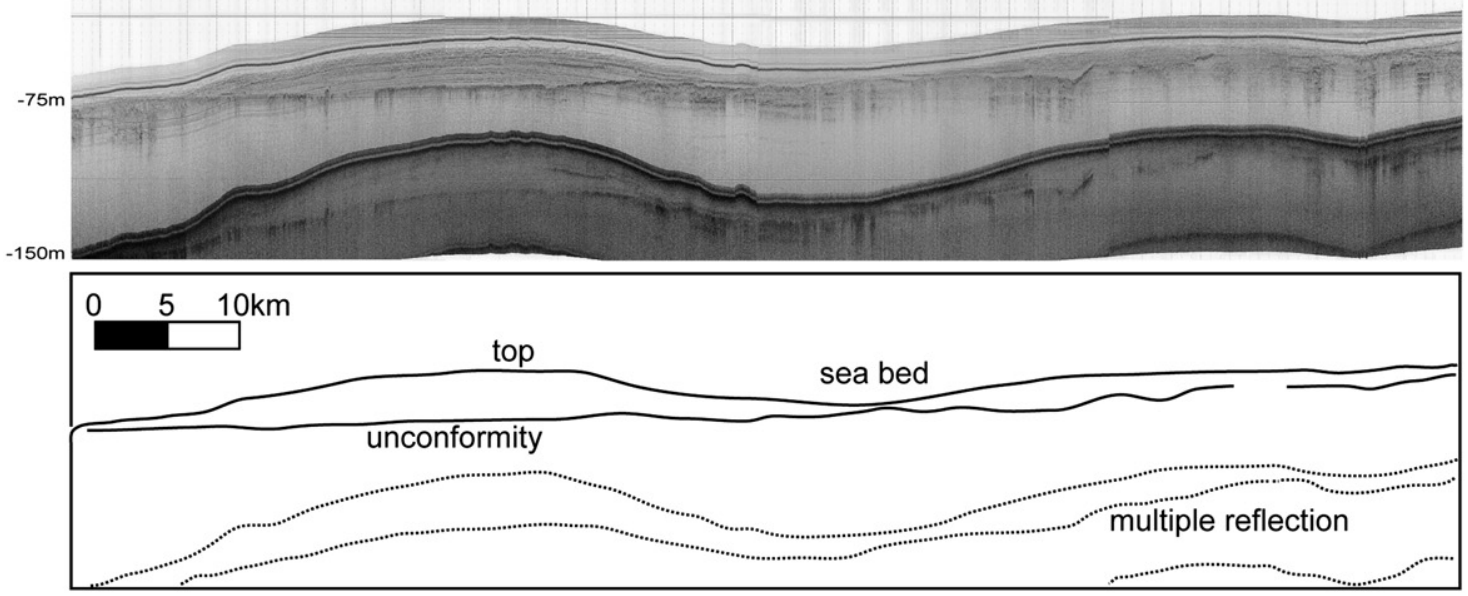

Om

$731 \mathrm{C}-6$
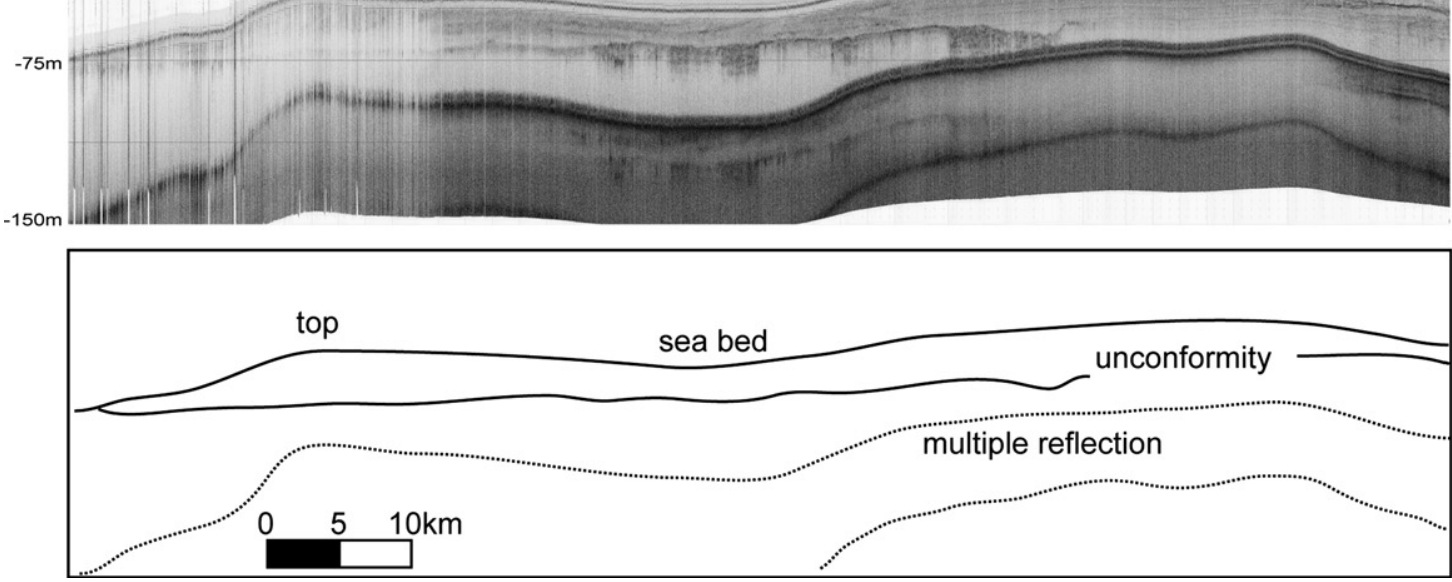


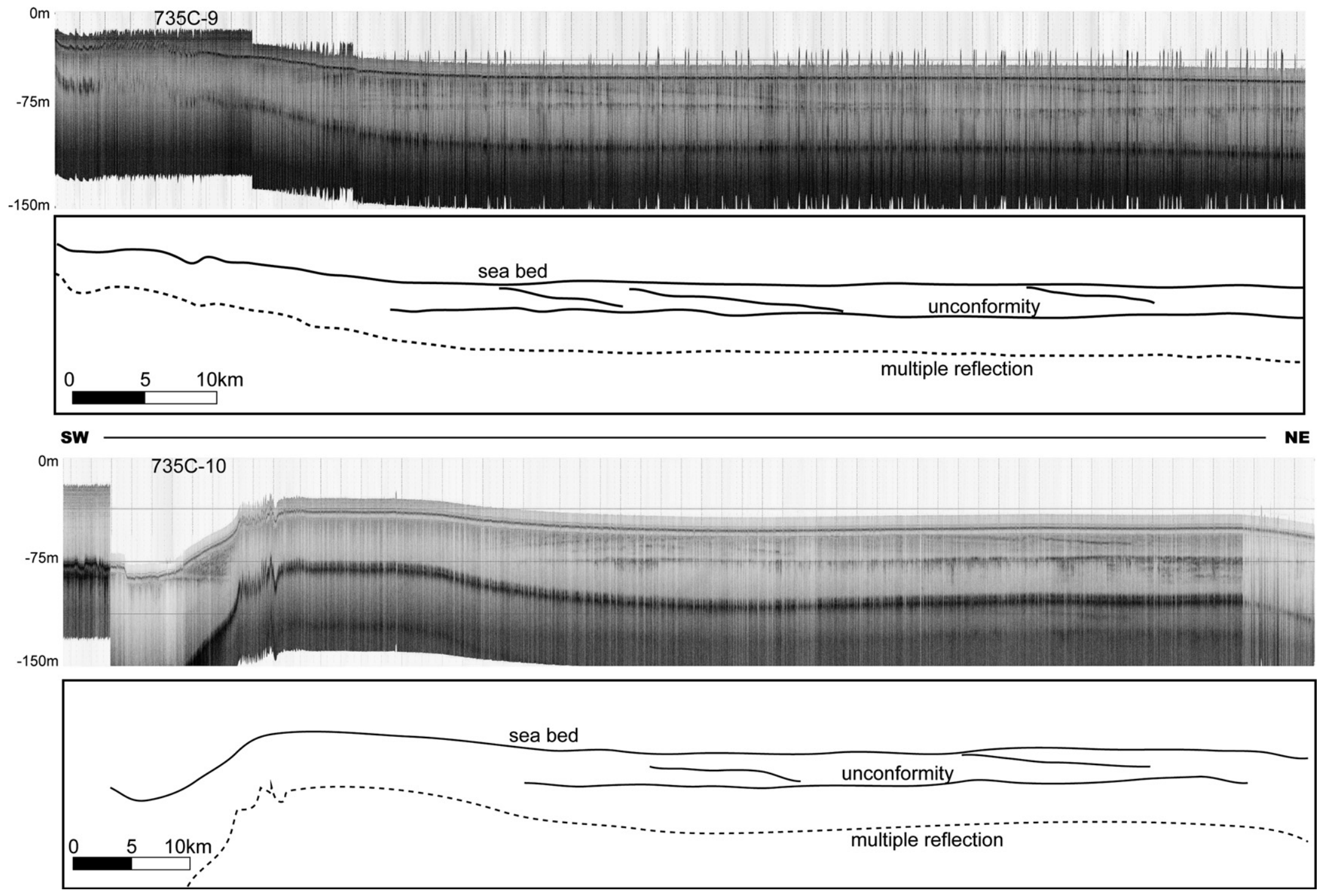

Fig. 7. Longitudinal chirp sonar profiles of 735C-9 and 735C-10 along the sand shoal show different internal structures of the sand shoal with additional short inclined reflectors dipping northeast between the sea bed and the relatively flat basal reflectors. Locations of chirp sonar profiles are shown in Fig. 4. 
Table 1

Summary of major features of sand bodies of the Changyun Ridge, Taiwan Strait

\begin{tabular}{llll}
\hline & Sand ridge & Sand shoal & Sand sheet \\
\hline $\begin{array}{l}\text { Location (distance off } \\
\text { Taiwan western coast) }\end{array}$ & $30 \mathrm{~km}$ & $60-80 \mathrm{~km}$ & $80-90 \mathrm{~km}$ \\
$\begin{array}{l}\text { Morphology } \\
\text { Orientation }\end{array}$ & Ridge & Shoal & Sheet \\
Sediment grain size & NE-SW & NW-SE & NE-SW \\
& $\begin{array}{l}\text { Medium-to- } \\
\text { coarse sands }\end{array}$ & Fine-to- & Fine- \\
& & sands & grained \\
Sand waves & Seldom & Occurring & Absent \\
& occurring & widespreadly & \\
Tidal ellipses & Narrow & Broad rotary & Broad rotary \\
& reciprocal & & \\
\hline
\end{tabular}

shape of the head and the tail of the east Changyun ridge is not obvious (Fig. 2c), providing positive evidence for sand movement. The presence of several short inclined reflectors dipping northeast and down-lapping the basal flat reflector indicates that sands are most likely transported from south to north for the sand shoal (Figs. 6 and 7).

Since sand bodies of the Changyun Ridge are of hydrodynamic origin, the tidal currents therefore have the most important effect on the accumulation of sands of the Changyun Ridge. The velocity and the semidiurnal tidal ellipses of the tidal currents in the Taiwan Strait provide important clues for sediment transport of sand bodies of the Changyun Ridge. Patterns of semidiurnal tidal ellipses in the Taiwan Strait are superimposed on the sand bodies of the Changyun Ridge to determine the sediment transport direction (Fig. 8). North-flowing tidal currents with narrow semidiurnal reciprocal rectilinear tidal ellipses occur mainly over the eastern Changyun Sand Ridge, indicating that sands are mainly transported to the north (Fig. 8).

Broad semidiurnal rotary ellipses are oriented NESW and appear over the sand shoal, suggesting that sediment is transported to the northeast. This inference is contradicted in the NW direction of sand transport inferred by the morphology of sand bodies. However, the net current flows are deflected to the northwest direction along the southern edge of the sand shoal (Fig. 3). Therefore, sands are moved mainly by net current flows rather than by the tidal currents, resulting in deposition of the sand body oriented in a NW-SE direction. Farther west, relatively broad rotary semidiurnal tidal ellipses oriented NE-SW are distributed on the sand shoal, indicating sands being transported to the northeast. It is noted that the morphology of the sand bodies changes from a typical sand ridge (the eastern Changyun Sand Ridge), a transition to a sand shoal and finally to a sand sheet of the Changyun Ridge over a distance of more than $90 \mathrm{~km}$ across the strait. Changes in morphology of the Changyun Ridge may be related to a corresponding progressive decrease in velocity of tidal currents and the hydrodynamic conditions. Similar relationships between sand bodies morphology and tidal current patterns are observed in the Bohai tidal sea shelf where sand ridges are dominated by strong rectilinear currents with relatively narrow ellipses whereas currents with relatively broad ellipses are prevalent over sand sheets (Liu et al., 1998).

Lin et al. (2005) reported the most up-to-date tidal current observations in the Taiwan Strait, showing one station at the northern outlet of the Penghu Channel with consistent north-flowing tidal currents (Fig. 8). Measurements at four stations across the central Taiwan Strait located north of the sand bodies of the Changyun Ridge show that tidal currents, oriented NE-SW, are characterized by velocities of less than $0.6 \mathrm{~m} / \mathrm{s}$ and by broad rotary semidiurnal tidal ellipses (Fig. 8). These observations are comparable to early documentation of tidal currents in the Taiwan Strait (Wang et al., 2003). The systematic change in tidal current velocity and orientation in the Changyun Ridge region could be responsible for the observed progressive change in grain size of the surface sediments on the Changyun Ridge (Fig. 5). Therefore, sedimentation of sand bodies of the Changyun Ridge is mainly controlled by the tidal currents, i.e., the transport and accumulation of sands available from the source areas from the south.

\subsection{Hydrodynamic origin}

The presence of sand waves on sand ridges indicates that a sand ridge is active (Park et al., 2003). The difference in the distribution of sand waves between the western and eastern ridges suggests that the western and eastern ridges are affected by different hydrodynamic processes.

The direction of peak currents is usually oriented at an angle to the crest lines of large sand waves (Dalrymple 1984; Lanckneus et al., 1994). There are opposite asymmetrical profiles between the contract flanks. The reversing slope angles observed on the crest and flank of the sand ridge suggest bidirectional currents. The sand waves on the crest are mainly formed by northeast flowing currents, probably being flood tidal currents. In contrast, sand waves on the other flank respond mainly to southwest flowing currents probably being ebb tidal currents. It implies that the shape and the 

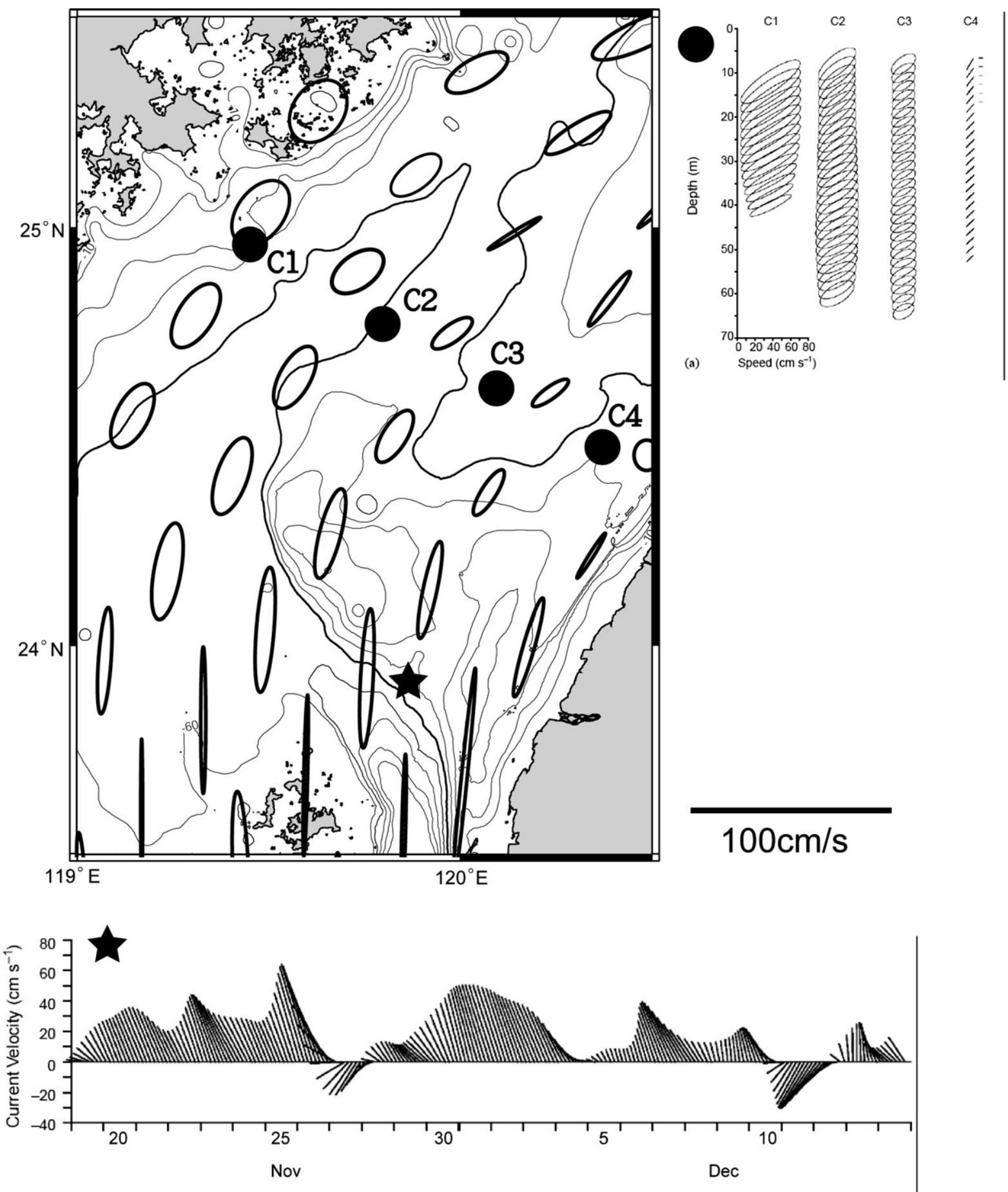

Fig. 8. Patterns of semidiurnal tidal ellipses in the Taiwan Strait (Wang et al., 2003) are superimposed on the Changyun Ridge. The eastern Changyun Sand Ridge is dominated by narrow reciprocal rectilinear tidal ellipses, whereas broad rotary tidal ellipses are prevalent over the sand shoal and the sand sheet. The star symbol indicates the station recording consistent north-flowing tidal currents from the Penghu Channel. Solid circles represent four stations across the central Taiwan Strait showing that tidal currents oriented NE-SW are characterized by a velocity being generally less than $0.6 \mathrm{~m} / \mathrm{s}$ and by broad rotary semidiurnal tidal ellipses. After Lin et al. (2005). 

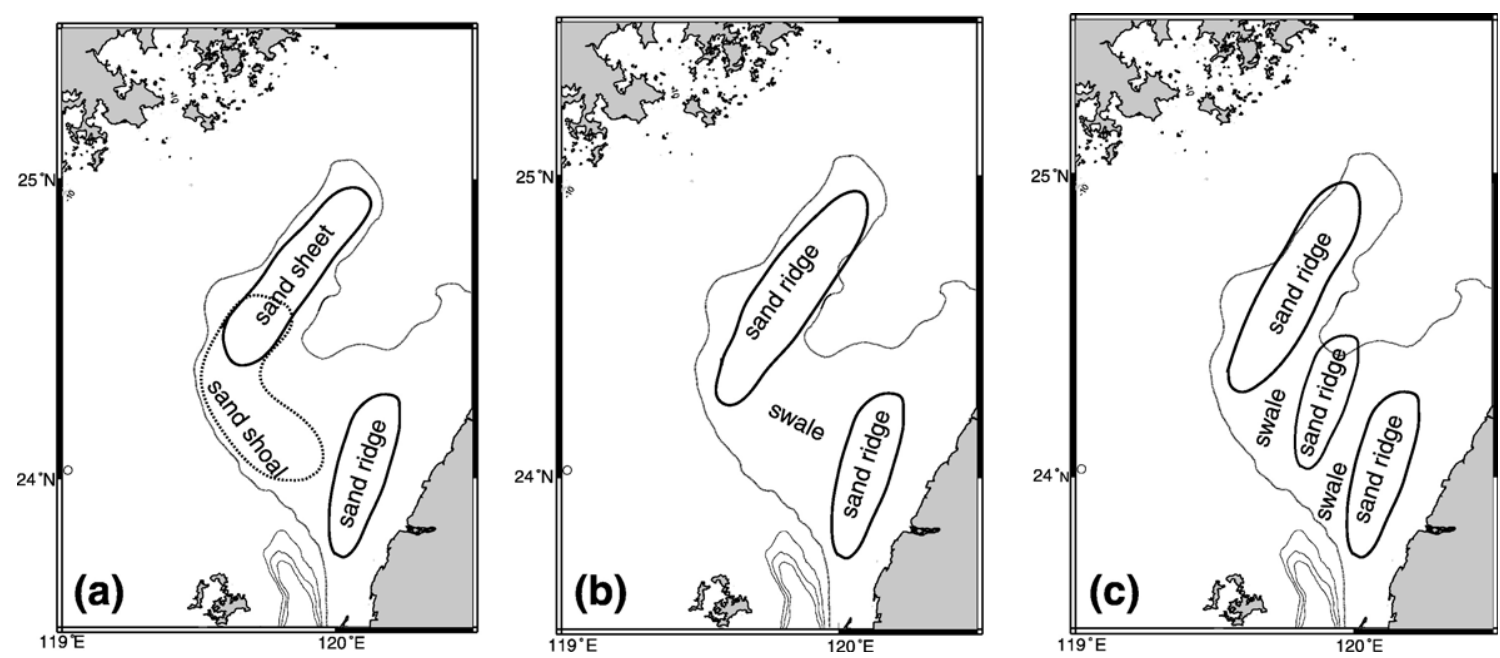

Fig. 9. Schematic diagram showing a postulated evolution of the Changyun Ridge. The present special distribution of sand bodies (a). Subsequently, the kink or bending of the ridge-like sand body and sand ridge may have disappeared to form a single sand ridge (b) or two parallel sand ridges separated by swales (c).

size of the eastern Changyun Ridge remain more or less the same at the present time, resulting from a near balance of addition and removal of sands. By contrast, the western sand shoal continues receiving sand supply from sources. So the eastern ridge is moribund and the western one is active.

We deduced from the orientation, shape and associated hydrodynamics of these sand bodies to infer their activity of sedimentation, in addition to the presence or absence of sand waves. In a conceptual model of sand ridge development, mature sand bodies are characteristic of elongate ridges with dimensions similar to those of typical sand ridges (Dyer and Huntley, 1999). The east sand ridge has an elongate shape and is about $65 \mathrm{~km}$ long and $15 \mathrm{~km}$ wide, similar to that of typical sand ridges (Dyer and Huntley, 1999). The orientation of the east sand ridge is nearly $\mathrm{N}-\mathrm{S}$ and parallel to the long axis of the dominant tidal currents on the eastern Taiwan Strait shelf. The orientation is compatible to the northwards direction of net sand transport. Therefore, we inferred from observations of morphology and currents patterns that the east sand ridge has developed to a mature stage and maintained its present dimensions and orientation at a stable condition of sedimentation.

By contrast, the west sand body is about $53 \mathrm{~km}$ long and $26 \mathrm{~km}$ wide, trending northwest-southeast oblique to the long axis of the dominant tidal currents. The west sand body is not similar to typical sand ridges in terms of shape and orientation. Comparing the characteristics of morphology and associated direction of tidal currents of the west sand body to those of the east sand ridge, we suggest that the west sand ridge has not developed to a mature stage and is ceaselessly receiving sands mainly derived from south, towards the dimensions and orientation of the east sand ridge. Hence, the west sand body is active in terms of accumulation of sands. Furthermore, in a postulated sand ridge evolution scheme, sands would continue to accumulate over the west sand body and eventually the kink area breaks and results in more than one newly formed sand ridges similar to the east sand ridge, assuming continued and enough sand supply from the south. This is a preliminary and hypothetical interpretation.

Considering the internal structure of sand bodies, two types of tidal sand banks can be distinguished. The first type of sand bank rests on a flat surface on which sands derived from the source area are deposited (Houbolt, 1968; Belderson et al., 1982; Hulscher et al., 1993; Trentesaux et al., 1994, 1999). This suggests a hydrodynamics-dominated origin of these sand ridges. The second type of sand bank is formed by sand accumulation around a pre-existing sediment body or sedimentary core (Houbolt, 1968; Laban and Schuttenhelm, 1981; Yang, 1989, Berné et al., 1994, Snedden and Dalrymple, 1999). They consist of cores of eroded fluvial, estuarine sediments or bedrock material, usually of early Holocene or Pleistocene age. These sand banks thus have a polygenetic origin.

Three transverse and two longitudinal chirp sonar profiles over the western Changyun sand bodies are presented to reveal the internal structures and to determine the thickness of sand accumulation (i.e., height of sand body) and finally to infer the possible origin. Profile $731 \mathrm{C}-4$ across the long axis of the sand 
shoal shows the presence of a relatively flat reflector underlying the main sand body (Fig. 6). The bottom reflector dips towards the northwest with a very gentle slope and gradually merges with the adjacent sea floor at about $75 \mathrm{~m}$ water depth. The height of the sand sheet is then determined from its crest to the bottom reflector, being about $22 \mathrm{~m}$. Further south, the $731 \mathrm{C}-5$ and $731 \mathrm{C}-$ 6 chirp profiles cross the sand sheet, the swale and the northern end of the eastern Changyun Sand Ridge. Profile $731 \mathrm{C}-5$ shows that a relatively flat reflector is underlying the sand sheet, which can be traced into that appearing on Profile 731C-4 to the north. The height of the sand sheet can be determined by the difference in depth between the top of the sand sheet and the basal reflector. It ranges from 22 to $25 \mathrm{~m}$ in thickness. This shallow flat reflector extends south-eastward into the sand body of the northern part of the eastern Changyun Sand Ridge where a sub-horizontal reflector with low relief is present (Fig. 6).

Profile 731C-6 shows a sub-horizontal bottom reflector beneath the sand sheet and the swale and the western part of the eastern Changyun Sand Ridge. The inferred thickness of sand accumulation above this basal reflector is comparable to that of the sand sheet, i.e. less than $25 \mathrm{~m}$. Longitudinal profiles of 735C-9 and $735 \mathrm{C}-10$ over the sand shoal and sand sheet (Fig. 7) show relatively flat basal reflectors below the top of the sand bodies. These basal flat reflectors are correlated to those shown on transverse profiles. It is noted that several short inclined reflectors between the sand sheet top and the basal reflectors prograde north-eastward and downlap the basal reflectors, indicating northeast transport of the sediments, parallel to the peak tidal current direction. Therefore, we suggest that the western Changyun sand bodies are probably formed on a flat surface where sands derived from a source area in the south are accumulated and built up. This implies that sand bodies in the Changyun areas probably are modern tidal sand deposits formed during the last major sea transgression, 15,000 years ago. The relatively flat basal reflector within the sand bodies is interpreted as the unconformity formed about 15,000 years ago during the sea level of low-stand in the Taiwan Strait (Boggs et al., 1979). The origin of sand bodies of the Changyun Ridge is mainly hydrodynamically controlled, as evidenced by chirp sonar data.

\subsection{Postulated sand ridge evolution}

It is noted that the tail of the sand shoal and the head of the sand sheet are connected instead of being two separate sand bodies. The bending or kink around the connection of the sand shoal and the sand sheet implies a transitional stage in the evolution of the Changyun Ridge (Fig. 9a). The mature stage of development of the Changyun Ridge is assumed to be two or three linear sand ridges separated by swales and oriented parallel to the long axis of the dominant tidal currents (Fig. 9b and c, respectively). Considering interactions between currents and sand movement, we postulate that currents transport sands north-westward and upslope, accumulating sands at the crest zone of the sand shoal. At the same time migration of the asymmetric sand shoal is in the direction of the steeper side towards the southwest. On the other hand, sands are transported by prevalent tidal currents flowing northeast and continue to accumulate over the sand shoal farther west. It is further speculated that the sand shoal may loose its elongated form and a small kink could occur due possibly to unequal transport rates (Caston, 1981). Following a longer-term evolution, the kink area could eventually break and result in more than one newly developed linear sand ridge parallel to the peak current direction.

\section{Conclusions}

The bathymetric mapping suggests that the so-called western Changyun Ridge (Liao and Yu, 2005) can be divided into two subunits: a sand shoal and a sand sheet. Chirp reflection profiles reveal the internal structures of the sand shoal, showing a relatively flat basal reflector underlying the sand body, suggesting a hydrodynamic origin. The height of the sand bodies or thickness of the sand accumulation is firstly determined by the depth difference between the modern sea bed and the basal reflector to better describe the morphology and to document dimensions of these sand bodies. The presence of several short inclined reflectors, dipping northeast and down-lapping the basal flat reflector indicate that sands are most likely transported from south to north for the sand shoal. Surface sediments of these three sand bodies show a progressive decrease in grain size from coarse to very fine sands with a typical sand ridge transition to a sand shoal. The variations of the hydrodynamic conditions (mainly tidal currents) on the central-eastern Taiwan Strait shelf are considered to be the primary control on sedimentary facies shift, morphological changes and sand ridge growth for the Changyun Ridge.

\section{Acknowledgements}

We thank the Captain, crew and technicians on board R/V Ocean Research I and II who helped to collect the 
marine data. Prof. J.C. Chen and Prof. Marc De Batist critically reviewed the manuscript. We thank National Science Council of Taiwan for financial support of this study.

\section{References}

Belderson, R.H., Johnson, M.A., Kenyon, N.H., 1982. Bedforms. In: Stride, A.H. (Ed.), Offshore Tidal Sands. Chapman \& Hall, London, pp. 27-57.

Berné, S., Trentesaux, A., Stolk, A., Missiaen, T., De Batist, M., 1994. Architecture and long-term evolution of a tidal sandbank: the Middelkerke Bank (southern North Sea). Mar. Geol. 20, 57-72.

Berné, S., Lericolais, G., Marsset, T., Bourillet, J.F., De Batist, M., 1998. Erosional offshore sand ridges and lowstand shorefaces: examples from tide and wave dominated environments of France. J. Sed. Res. 68, 540-555.

Berné, S., Vagner, P., Guichard, F., Lericolais, G., Liu, Z., Trentesaux, A., Yin, P., Yi, H.I., 2002. Pleistocene forced regressions and tidal sand ridges in the East China Sea. Mar. Geol. 188, 293-315.

Biq, C.C., 1997. Taiwan. In: Moore, E.M., Fairbridge, R.W. (Eds.), Encyclopedia of European and Asian Regional Geology. Central Geological Survey, Taipei, pp. 711-717.

Boggs, S., Wang, W.C., Lewis, F.S., Chen, J.C., 1979. Sediment properties and water characteristics of the Taiwan shelf and slope. Acta Oceanogr. Taiwanica 10, 10-49.

Caston, G.F., 1981. Potential gain and loss of sand by some sand banks in the Southern Bight of the North Sea. Mar. Geol. 41, 239-250.

Chuang, W.S., 1985. Dynamics of subtidal flow in the Taiwan Strait. J. Oceanogr. Soc. Japan 41, 65-72.

Chuang, W.S., 1986. A note on the driving mechanisms of current in the Taiwan Strait. J. Oceanogr. Soc. Japan 42, 65-72.

Covey, M., 1984. Lithofacies analysis and basin reconstruction, PlioPleistocene western Taiwan foredeep. Petroleum Geol.Taiwan. 20, 53-83.

Dalrymple, R.W., 1984. Morphology and internal structure of sandwaves in the Bay of Fundy. Sedimentology 31, 365-382.

Deleu, S., Van Lancker, V., Van den Eynde, D., Moerkerke, G., 2004. Morphodynamic evolution of the kink of an offshore tidal sandbank: the Westhinder Bank (Southern North Sea). Cont. Shelf Res. 24, 1587-1610.

Dyer, K.R., Huntley, D.A., 1999. The origin, classification and modeling of sand banks and ridges. Cont. Shelf Res., 19, $1285-1330$.

Fan, K.L., 1982. A study of water masses in Taiwan Strait. Acta Oceanogr. Taiwanica 13, 140-153.

Ho, C.S., 1988. An Introduction to the Geology of Taiwan: Explanatory Text of the Geological Map of Taiwan, 2nd edition. Ministry of Economic Affairs, Taipei. 192 pp.

Houbolt, J.H.C., 1968. Recent sediments in the southern Bight of the North Sea. Geol. Mijnbouw 47, 245-273.

Huang, Z.Y., Yu, H.S., 2003. Morphology and geologic implications of Penghu Channel off southwest Taiwan. TAO 14, 469-485.

Hulscher, S.J.M., De Swart, H.E., De Vriend, H.J., 1993. The generation of offshore tidal sand banks and sand waves. Cont. Shelf Res. 13, 1183-1204.

Jan, S., Chao, S.Y., 2003. Seasonal variation of volume transport in the major flow region of the Taiwan Strait: the Penghu Channel. DeepSea Res. II (50), 1117-1126.

Jan, S., Wang, J., Chern, C.S., Chao, S.Y., 2002. Seasonal variation of the circulation in the Taiwan Strait. J. Mar. System, 35, 249-268.
Jan, S., Chern, C.S., Wang, J., Chao, S.Y., 2004. The anomalous amplication of M2 tide in the Taiwan Strait. Geophy. Res. Lett., 31, L07308.

Laban, C., Schuttenhelm, R.T.E., 1981. Some new evidence on the origin of the Zealand ridges. In: Nio, S.D., Schuttenhelm, R.T.E., van Weering, T.C.E. (Eds.), Holocene Marine Sedimentation in the North Sea Basin. Spec. Publ. Int. Assoc. Sedimentlo., vol. 5, pp. 239-245.

Lanckneus, J., De Moor, G., Stolk, A., 1994. Environmental setting, morphology and volumetric evolution of the Middelkerke Bank (southern North Sea). Mar. Geol. 121, 1-21.

Liang, W.D., Tang, T.Y., Yang, Y.J., Ko, M.T., Chuang, W.S., 2003. Upper-ocean currents around Taiwan. Deep Sea Res. II (50), $1085-1105$.

Liao, H.R., Yu, H.S., 2005. Morphology, hydrodynamics and sediment characteristics of the Changyun Sand Ridge offshore western Taiwan. TAO 16, 621-640.

Lin, S.F., Tang, T.Y., Jan, S., Chen, C.J., 2005. Taiwan Strait current in winter. Cont. Shelf Res. 25, 1023-1042.

Liu, Z.X., Xia, D.X., Berné, S.K., Wang, Y., Marsset, T., Tang, Y.X., Bourrillet, J.F., 1998. Tidal deposition systems of China's continental shelf, with special reference to the eastern Bohai Sea. Mar. Geol. 145, 225-253.

Mao, S., Hsieh, I.H., 1989. Morphology of the Taiwan Strait. In: Nieh, S.P. (Ed.), The investigation and study on petroleum geology and geophysics in the western Taiwan Strait. Ocean Press, Beijing, pp. 22-34 (in Chinese).

Marsset, T., Tessier, B., Reynaud, J.Y., Be Batist, M., Plagnol, C., 1999. The Celtic Sea banks: an example of sand body analysis from very high-resolution seismic data. Mar. Geol. 158, 89-109.

Off, T., 1963. Rhythemic linear sand bodies caused by tidal currents. Am. Assoc. Pet. Geol. Bull. 47, 324-341.

Park, S.C., Han, H.S., Yoo, D.G., 2003. Transgressive sand ridges on the mid-shelf of the southern sea of Korea (Korea Strait): formation and development in high-energy environments. Mar. Geol. 193, $1-18$.

Reynaud, J.Y., Tessier, B., Berné, S., Chamley, H., De Batist, M., 1999a. Tide and wave dynamics on a sand bank from the deep shelf of the Western Channel Approaches. Mar. Geol. 161, 339-359.

Reynaud, J.Y., Tessier, B., Proust, J.N., Dalrymple, R., Marsset, T., De Batist, M., Bourillet, J.F., Lericolais, G., 1999b. Eustatic and hydrodynamic controls on the architecture of a deep shelf sand bank (Celtic Sea). Sedimentology 46, 703-721.

Snedden, J.W., Dalrymple, R.W., 1999. Modem shelf sand ridges: from historical perspective to unified hydrodynamic and evolutionary model. SEPM Special Publication vol. 64, 13-28.

Suppe, J., 1981. Mechanics of mountain building and metamorphism in Taiwan. Geol. Soc. China Mem. 4, 67-89.

Trentesaux, A., Stolk, A., Tessier, B., Chamley, H., 1994. Surficial sedimentology of the Middelkerke Bank (southern North Sea). Mar. Geol. 121, 43-55.

Trentesaux, A., Stolk, A., Berné, S., 1999. Sedimentology and stratigraphy of a tidal sand bank in the southern North Sea. Mar. Geol. 159, 253-272.

Wang, J., Chern, C.S., 1989. On cold water intrusions in the eastern Taiwan Strait during cold season. Acta Oceanogr. Taiwanica 22, 43-67.

Wang, Y.H., Jan, S., Wang, D.P., 2003. Transports and tidal current estimates in Taiwan Strait from shipboard ADCP observations (1999-2001). Estuar. Coast. Shelf Sci. 57, 193-199. 
Wang, Y.H., Chiao, L.Y., Lwiza, K.M.M., Wang, D.P., 2004. Analysis of flow at the gate of Taiwan Strait. J. Geophys. Res. 109, C02025.

Williams, J.J., MacDonald, N.J., O’Connor, B.A., Pan, S., 2000. Offshore sand bank dynamics. J. Mar. Systems 24, 153-173.

Yang, C.S., 1989. Active, moribund and buried tidal sand ridges in the East China Sea and the southern Yellow Sea. Mar. Geol., 88, 97-116.
Yu, H.S., 2003. Geological characteristics and distribution of submarine physiographic features in the Taiwan region. Mar. Georesour. Geotechnol. 21, 139-153.

Yu, H.S., Chou, Y.W., 2001. Physiographic and geological characteristics of shelves in north and west of Taiwan. Sci. China 44, 696-707 Series D. 